\title{
Ngebel Sumber Kabuyutan: The Reflection of Human and Natural Harmony Through Serat Centhini
}

\author{
Frengki Nur Fariya Pratama $^{1 *}$, Mudjahirin Thohir $^{1}$ \\ ${ }^{1}$ Master of Literature, Faculty of Humanities, Diponegoro University, Semarang, Indonesia
}

\begin{abstract}
In 2019, the issue of the impact of the PLTP construction in Ngebel Ponorogo was widely discussed. Reduced groundwater supply is one of the inherent impacts of geothermal drilling activities. In line with the mandate of Law no. 5 of 2017 concerning the Advancement of Culture implies old manuscripts/texts as one of the objects of cultural advancement, attention to Ngebel's ecological issues reminds us of early 19th century Javanese literary work entitled Serat Centhini. In Serat Centhini Volume VII pupuh 394. Wirangrong, pada 18 to pupuh 398. Gambuh pada 38 narrative records of various ecological wealth in Ngebel, as well as various water resources and syncretism rites of respect for natural resources which can be categorized as mystical-ecological. The discussion of narrative discourse through Serat Centhini is presented as a reflection of Ngebel Ponorogo ecological richness and the harmonization of humans and nature. Given the imagination during the Covid-19 pandemic, nature has again become the focus of human attention. Thus, the imagination of Ngebel's ecological wealth in the past emerged for consideration of Ngebel's environmental sustainability for the construction of PLTP (Geothermal Power Plant) and in general as an imagination of the harmonization of humans and nature.
\end{abstract}

\section{Introduction}

Nature Nature plays a vital role in the survival of human life. Nature provides a variety of human life needs that are related to him. With the development of technology, people are increasingly able to explore the natural resources available. One of them is geothermal potential, as done in Ngebel subdistrict, Ponorogo, East Java. The geothermal potential is processed and used as a resource for electricity generation or PLTP (Geothermal Power Plant).

The pltp development plan has been underway since 2014. PT Bakrie Power, owned by Aburizal Bakrie, and PT Medco Cahaya Geothermal, owned by Arifin Panigoro became the auction winner conducted by the Department of Energy and Mineral Resources (ESDM) East Java Province. Both companies are trusted to manage the entire pltp development project in Ngebel.

* Corresponding author: frengki.criss@,gmail.com 
The process of planning and construction of PLTP does require a long time. From 2014 to 2021, PLTP Ngebel does not appear to be operational. The development phase has also drawn criticism from environmental activists. The official website of Walhi (Wahana Lingkungan Lingkungan Indonesia) East Java and LPM Al-Milah IAIN Ponorogo magazine are among those who have raised the issue of the impact of the development of Pltp Ngebel.

Based on the official website walhi Jatim shows the fracking process pltp Ngebel has a negative impact. The $\mathrm{f}$ racking process causes the fracking of various chemicals that are harmful to the environment. Contamination of chemicals used in the fracking process can contaminate the water sources of the surrounding residents. In addition to minor earthquakes, soil ambles and greenhouse substances arise from fracking activities [2].

Meanwhile, LPM Al-Millah IAIN Ponorogo magazine more detailedly investigated the impact of the construction of PLTP Ngebel. Magazine issue 36 the year 2019 titled PLTP: Melukai Alam Demi 120 Megawatt broadly alludes to the impact of the water crisis from the construction of PLTP on the environment Ngebel. Related to water sources, PLTP Ngebel stems the flow of the Deram river for its operation. The water used for operations was calculated to consume 912,000 liters/day, equivalent to the daily consumption of 13,028 inhabitants [3].

A survey conducted in colonial times from 1916 to 1917 on irrigation development plans in Ngebel informed that the Deram river is the main route of water supply in the northern part of Ngebel to Madiun [4]. Semenok Village (Colonial Government wrote Semenak), which has a steep and narrow contour with a ravine as high as $40 \mathrm{M}$, was initially planned to be built a tunnel to drain water to Madiun. Moreover, in semenok area, ancient solid volcanic products are also found that line the walls of the river gorge Deram [4]. This record assumes the existence of heat deposits of former volcanoes in the past. The results of the investigation of LPM Al-Millah also found that in Semenok digelontorkan CSR funds (Corporate Social Responsibility) pre-development of the company responsible for the construction project pltp Ngebel. Most likely, the nature of Semonok area will be most affected by the construction of PLTP.

The special coverage notes stated that the construction of pltp has disrupted the flow of water to the hamlets of Ngrogung, Sempu, and Ngresik [3]. Geothermal or geothermal exploration problems do threaten groundwater supply. With this problem, it is essential to present discourse of the past to remember the abundance of water sources in the Ngebel area, as one of the narratives that the water in this article is symbolized as a sumber of being kabunyutan or sacred place because it is so vital for human life, as written in Serat Cenhtini. Indeed through cultural treasures whose validity should be considered. The mystical-ecological narrative of the water sember is found in an old manuscript entitled Serat Centhini made in 1814 AD.

The importance of revealing the context written in a manuscript, as in this article, is also emphasized by Oman Fathurahman. According to him, philologists do not just present text that is ready to read. However, moreover, philologists must also present an appropriate and in-depth context of a particular text [6]. In line with that, Hoesein Djajadiningrat in Oman Faturahman said that the presented context would provide an overview of the concepts and views of the past society.

The narrative reflection of a manuscript like this was also done by Dwi Woro Retno Mastuti, who criticized the arrogant attitude of the owners of power [7]. In his writings, the narrative of the text presented takes curse stories from kakawin smaradahana (1185 AD), Mahabharata (918 AD), and Sumanasantaka (1204 AD). In addition, Oman Faturahman constructed the local Islamic history in Minangkabau through various manuscripts produced in Minangkabau [6]. This article confirms that manuscripts can be used to uncover various aspects of the historical and life view of the people of an area. 
This paradigm is in line with UU No. 5, 2017, about Pemajuan Kebudayaan, which mentions ancient manuscripts as objects of cultural development. This manuscript was presented as a step to study the ecological wealth of Ngebel area recorded in the manuscript and hacking the distance between the community and the context (Ngebel) recorded in Serat Centhini. This narrative is used as one of the steps on the problems still discussed in ngebel area, Ponorogo, East Java Province.

\section{Ngebel Notes in Serat Centhini}

Serat Centhini was written on the initiative of KGPAA Hamengkunagara III (Sunan Pakubuwana V) assisted by R.Ng. Ranggasutrasna, R. T. Sastranagara and R.Ng. Sastradipura and also assisted by Prince Junggut Mandurareja, Kiai Kasan Besari and Kiai Mohammad Minhad. The manuscript is a candra sengkala colofons of the Paksi Suci Sabda $\boldsymbol{J i}$ or 1742 Jawa (1814 AD). This literary work of Pakubuwana IV period consists of 12 volumes containing various javanese cultural emanations. While Ngebel is recorded in volume VII as one of the places of visit Seh Amongraga in his odyssey.

Seh Amongraga's odyssey is detected from the dialogue between Seh Amongraga and Jamal and Jamil in Pupuh 394. Wirangrong. They departed from Trenggalek to Telaga Ngebel on the slopes of Mount Wilis pranaraga area as follows [5]:

Wus payo padha lêstari | ngêncêng kewala mangulon | nulya sami lampah sêdyanipun | marang gunung Wilis | tanah ing Pranaraga | karsane anjajah desa || (Pupuh 394. Wirangrong Pada 19)

Translation:

After recovering | continue west of $\mid$ walk together with the intention of $\mid$ to Mount Wilis | Pranaraga land | with the aim of exploring || village

Karsanira Sèh Mongragi | mring têlaga Bêl kinaot | samining têlaga tan kadyèku | pan agêng pribadi | nèng pucaking prabata | praptèng sukuning panjatan ||

(Pupuh 394. Wirangrong Pada 26)

Translation:

The Will of She Amongraga | towards ngebel lake which is more | than any other lake | looks bigger | on the top of mount | to the foot of the ||

Based on the book Babad Ponorogo volume 1 by Purwowijaya, Ponorogo comes from the combination of the word pramana and raga that became Pranaraga. In its development, it changed to Panaraga [9]. Due to the adjustment to the Spelling of Indonesian, the word Panaraga changed to Ponorogo with the vowel "O."

Ponorogo, as one of the areas under the Resident Madioen, in the Dutch colonial period, became a place that is so taken into account because the landscape is so unique. In Encyclopaedie van Nederlandsch-Indie, Ponorogo was recorded as a research site for various types of plants by colonial botanical researchers (Herbarium) in addition to Saradan and Sarangan [10].

Related to the type of plant, recorded on pupuh 394 Wirangrong to pupuh 398 Girisa. Ngebel is told as a beautiful place, filled with plants that are very diverse ranging from Gadhung, Suwêg, Uwi, Gêmbili, Kimpul, Jugul, Kara (pupuh 397 Maskumambang pada 13) Kêpêl, Pêlêm, Kêmlaka, Pakèl, Kuwèni, Sawo, Sarangan, Kokosan, Duryan, Manggis, Gowok, Kêtos, Bêntis, Nanas (pupuh 397 Maskumambang pada 14) Mundhu, Andhi-andhi, Kêleca, Kêcapi Pucung, Pace, Pucang, Kucacil, Dhuku, Wuninga, Wênèh, Bêndha, Dhuwêt, Nangka (pupuh 397 Maskumambang pada 15) Jambu Wèr, Kêlampok, Kluthuk, Maja, Jêram, Gayam, Sêmpu, Sêntul, Widara, Rambutan (pupuh 397 Maskumambang pada 16) 
Pête, Jengkol, Kumlandhingan (pupuh 397 Maskumambang pada 17) and Taun wood around the lake,

In addition to diverse plants, Ngebel is also recorded in Serat Centhini has several sources of water (sendhang) among others:

Sumber Selapati, Sumber Padusan/Sumber pasiraman, Sumber ngamuning, Sumber Bêth ara, Sumber Ngarnini and Sumber Upas. This finding was then interpreted in Ngebel. The matching of the source in Serat Centhini's text is done by interpreting the text based on the geographical imagination written in Serat Centhini with an image of a colonial map close to the year-long range of Serat Centhini writing [4]. The most obvious reference is seen from the name of the mountain, the name of the village/place name, and the recorded trip description.

The name of the place was recorded and can still be found Watu Saba Hamlet. This hamlet is located on the west side of the lake ngebel, which originates from angganala figures accompanying Seh Amongraga, Jamal, and Jamil around Ngebel lake. This hamlet is located to the east of Sekodok hamlet where the border friction occurred between Yogyakarta Palace (Raden Rongga Prawiradirja III) and Surakarta (Mas AryoWiryodiningrat) in 1810 AD [11].

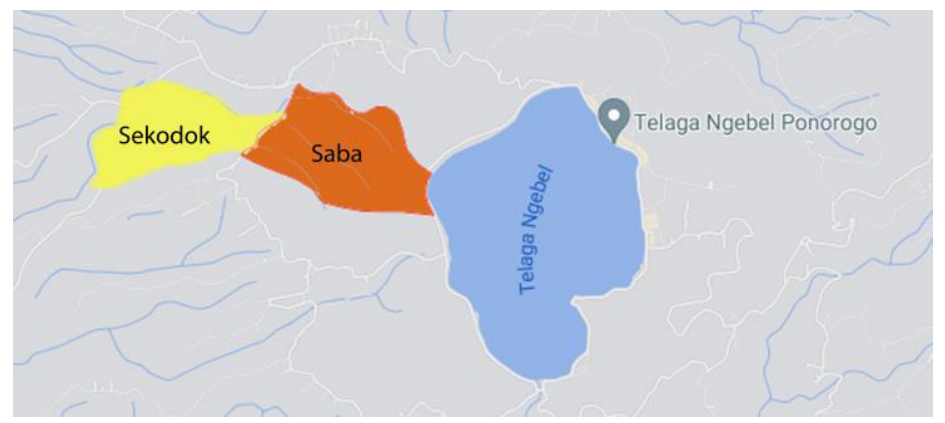

Fig. 1. Sekodok-Saba.

Based on the historical allusions, the assumption that the context of the place name recorded in Serat Centhini (especially the text on Ngebel) is based on the reality of the Ngebel area. Second, refers to the names of the mountains around the lake, among them: ardi Karang, ardi Sela-awak, ardi Sela-panggêl, ardi Sela-tambak, ardi Tunggangan, ardi Watukowok, ardi Manoara, ardi Balêlatu, ardi Calam-agung, ardi Sampèlwatan, ardi Patukan, ardi Pathokan, ardi Kêkêndhêng,ardi Pêragak, ardi Kumambang, ardi Sêdhacin, ardi Soka and ardi Bunglegi. Some of the mountains recorded in Serat Centhini can be traced through colonialmade maps in 1916-1917 on plaat XXXI [4]. 


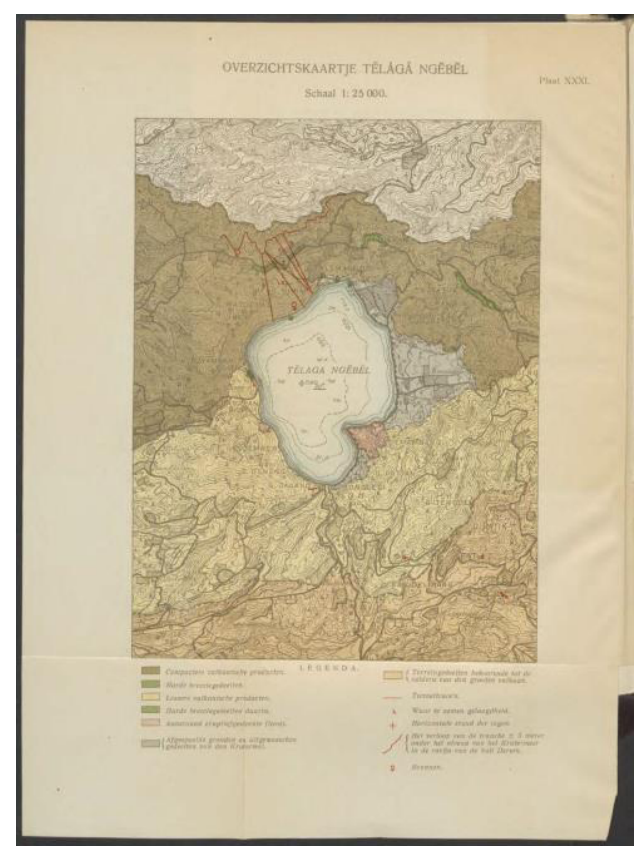

Fig. 2. Plaat XXXI.

Refer Figure 2. Plaat XXXI found the names Of Mount Bajoelirang, Tengoek, Batik, Dagang, Geneng, Soemoer, Dadapan, Gampil, Pratjekan, Djembangan, Bakor, Semampir, Betoro, Boentoeng, Tambak, Watu-awe, Noara, Bale Mankok, Koemambang, Datjan and Bong Legi. There are seven mountain names that can be interpreted to have similar names, namely: 1). Sela Tambak-Tambak; 2) Watu Kowok-Watu-Awe; 3) Manoara-Noara; 4) Bale Latu-Bale Mankok; 5) Kemambang-Koemambang; 6) Sedhacin-Datjan; 6) Bung Legi-Bong Legi.

This difference may be due to the difference between the creation of Serat Centihini (1814) and the map creation period (1916-1917), which was 103 years. Such a long distance is very likely to change the designation of mountains in the community. It is also possible that there are limitations on the interpretation of map makers with Javanese words. Similarly, it is possible that some of the mountain designations were taken or changed to the name of the hamlet/village and Ardi Soko, which can now be found similar to the area named Sooko in Ponorogo. However, from the many mountains recorded, Bung Legi can be used as a guide for interpretation through the map (Figure 2. Plaat XXXI) to browse the locations recorded in Serat Centhini. Thus, the accuracy of the location of reality with the interpretation of Serat Centhini text can be obtained better.

With the help of the intertextuality of reference sources, water sources recorded in Serat Centhini can be proven to exist. Some water sources that still exist and are successfully found in Ngebel, including the following:

\subsection{Sumber Padusan}

Padusan source is mentioned in Serat Centhini Pada (pupuh 395. Girisa Pada 15) as the source of kabuyutan. Described in Serat Centhini, Sumber Padusan is oblong in shape, with a slightly tilted position. Located on a large white (limestone) rock located at the corner of the street. 
Wangsul mubêng marginira | ingkang lèr-kilèn prênahnya | pojoking mêrgi tikungan | nèng karang gêng sela pêthak | tuking toya ambêlumbang | tan bundêr datan pêsagi | pan lonjong enggok-enggokan | miring pasanging bêlumbang ||

(Pupuh 395. Girisa Pada 24)

Translation:

Finish down | road northwest of the | corner of $\mid$ street corner on a large white coral | water source in the | pond not round not square | but oblong | the slope of the pool is ||

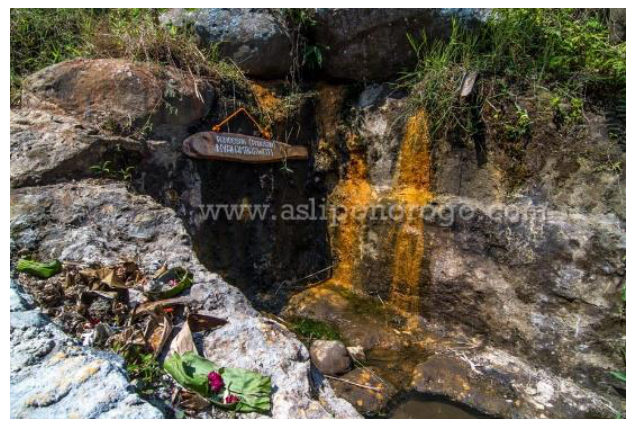

Fig. 3. Sumber Padusan (www.asliponorogo.com).

In addition to the description of Sumber Padusan, Serat Centhini also notes the myth that this place is the bath of Suralaya angel. In the eastern part, this source is also widely used for bathing and seeking blessings. All kinds of evil will disappear at this source. Thus, when entering the Padusan Source, it must be in good faith [5].

Referring to the description in Serat Centhini, Sumber Padusan refers to the source located in the village of Pandusan Wagir Lor village Ngebel subdistrict. This source is also named Sumber Padusan, which later changed its name to Tirto Husodo. This source is a natural hot spring located by the river.

The story that people believe also has similarities with the description in Serat Centhini, namely the figure of a goddess or angel as a female figure who waits for this exact. According to Suprapto, this source is the place of ascetic Dewi Ambarwati. Now, this resource has become a natural hot spring tourist spot in Ngebel sub-district. The surrounding community also believes this source can cure various diseases suffered. Similarly, with the ritual of seeking blessings, the people of Ponorogo and its surroundings still do and believe it. Ubarampe rituals such as kembang setaman, black coffee, and eggs are still found in this place.

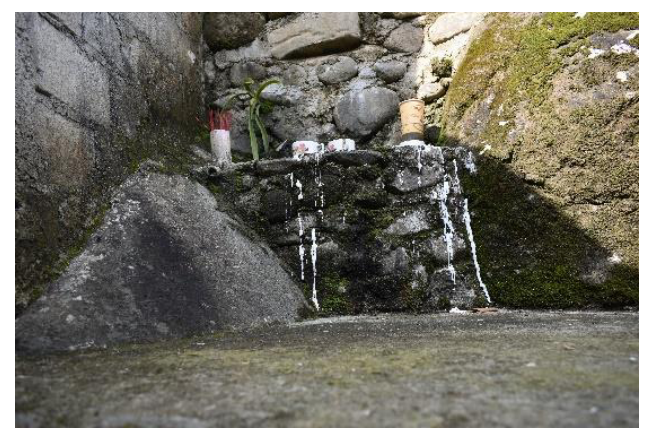

Fig. 4. Sesaji di Sumber Padusan (Doc. Personal).

Related to the name difference between Widadari Suralaya and Dewi Ambarwati needs to be further reviewed. However, the figures of Widadari Suralaya and Dewi Ambarwati, 
who are sacred, have similarities to those of Danyang, who inhabit this source. The two also have gender equality, namely women. This can be related to the Javanese genealogy that symbolizes women as guardians of the earth, even gender for the earth (universe).

\subsection{Sumber Bethara}

Sumber Bethara is mentioned in Serat Centhini in (Pupuh 396. Mijil Pada 29) as a benchmark for the depth of ngebel lake in the southeast of the central part [5]. Sumber Bethara is known as Kucur Betoro, as shown below.

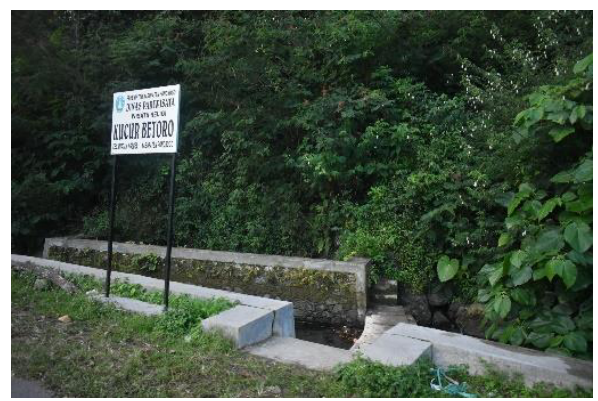

Fig. 5. Sumber Bethara (Doc. Personal).

Kucur is also defined as a source that pours out of the ground has similarities with the name of the Sumber. Bethara and Betoro have similar meanings to the title of god. The difference in this writing lies in the use of Javanese spelling with Indonesia. The second assumption refers to the results of Dr. G. J. N. Hengeveld's report in Figure 2. Plaat XXXI. The location of Kucur Betoro is close to a mountain named Betoro. The possibility of naming is based on the location of the mountain closest to the water source.

Sumber Bethara or Kucur Betoro is on the side of the road southeast of the lake. This place by the government is designated as one of the religious tourism assets, as evidenced by the installation of the name plang. Unfortunately, many citizens do not know and care about the existence of this source. Only a handful of people understand the existence and function of this Bethara source.

According to the Dodo, this source is used as one of the water sources for washing heirlooms(jamasan) in the month of Suro by the Government of Ponorogo. Jamasan Pusaka itself is an annual ritual ceremony of Ponorogo regency, as a series of commemorations of the founding day of Ponorogo regency. Another story that circulated, this source is believed to be the place of purity Raden Bathara Katong before promoting Islam in the land of Wengker. Two sources are coming out of the ground at Sumber Bethara precisely with the description mentioned in Serat Centhini.

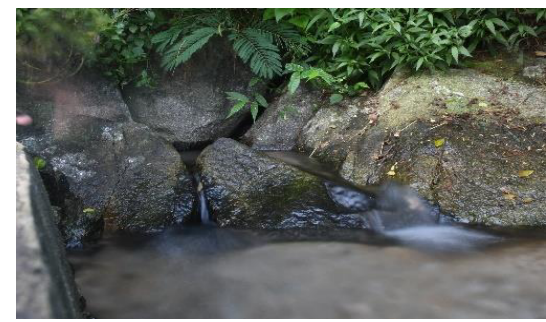

Fig. 6. Mata Air Sumber Bethara (Doc. Personal). 
The difference is Serat Centhini mentions the source of water coming out of the lake. But this source is located on the edge of the cliff close to the lakeside road.

\subsection{Sumber Ngarnini}

Sumber Ngarnini is mentioned in Serat Centhini in (Pupuh 397. Maskumambang Pada 4) as a benchmark of the depth of ngebel lake [5]. This source is known to ngebel people as the source of Kernini. This source is to the north of Kucur Betoro or Sumber Bethara. The source located in this lake is north of the irrigation waterway from the east, west of the mosque near the lake.

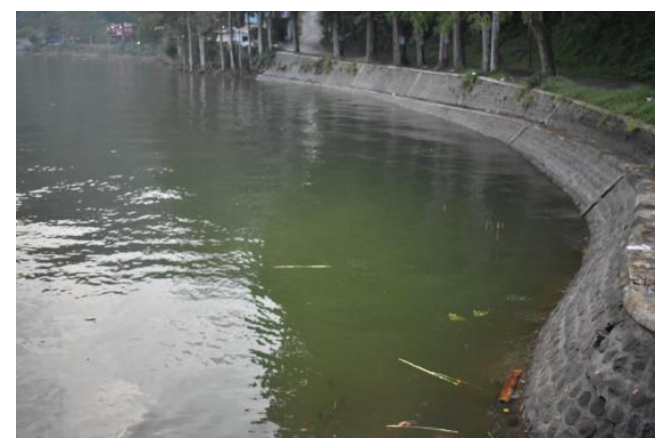

Fig. 7. Sumber Ngarnini (Doc. Pribadi).

Information from residents of this source can be seen when the lake water recedes. Located next to a large stone located in the lake Ngebel. This water sources used to be, when the lake was not as wide as it is now can still be witnessed. However, over time there is erosion of lake water that causes the spread of the lake and added the discharge of lake water becomes the cause of this source covered by water. However, the location of Sumber Ngarnini needs to be investigated further because there has not been found more accurate evidence.

\section{Sumber Kabunyutan and Harmonization of Nature-Man}

In addition to the three sources (Sumber Bethara, Padusan and Ngarnini) that have been traced to its existence, there are several water sources listed in serat Centhini records namely Sumber Ngemuning, Sumber Upas and Sumber Selapati. Related to the Sumber Selapati in Serat Centhini is recorded as the source that became the benchmark of water waves, murkyclear and the tides of Telaga Ngebel water [5]. As in Serat Centhini text below:

Dhatêng ing sumbêr pun Upas | (ng)gih nênêm kathahing sêndhang | sakêlangkung angkêrira $\mid$ wus datan kêna sinaba $\mid$ pun tlaga Ngêmbêl punika $\mid$ manut sumbêr Selapati | lamun kocak tumut kocak | tuwin warnane ing toya ||

(395. Pupuh Girisa Pada 16)

Translation:

Located at Upas | source 6 number of sendhang | very haunted | unexplored | Ngebel's lake | follow Selapati |'s source if you're beaking | and the color of the water ||

Buthêk wêning pita rêta | tlaga Bêl purut kewala | sumbêr Selapati we-nya | Sèh Mongraga ris ngandika $\mid$ payo padha pinaranan $\mid$ manira ayun amirsa $\mid$ sira lumakuwèng ngarsa | prênahe sumbêr tuduhna || 


\section{(395. Pupuh Girisa Pada 17)}

\section{Translation:}

Murky clear yellow red | Bel lake always follows | the water is the Sumber Selapati | She Amongraga spoke softly | Let's all go there | I want to see it | You're in front of | show me where the source is $\|$

This indicates that the existence of Ngebel lake depends on the existence of water sources around it, regardless of the myth that surrounds ngebel lake with Sumber Selapati. Considering the Sumber Dukun, Sumber Seklithik, and Sumber Banyu Mili, some water source data obtained in the field boils down to Telaga Ngebel [5]. The paradigm on the importance of water sources interpreted in Serat Centhini text is also wrapped in the myth of sacredness or kabuyutan. Sumber Selapati, Sumber Padusan, and Sumber Upas located in the south, precisely from Bung Legi down to the east, are all used as places of tawakuf Seh Amongraga and sacred society in the text Serat Centhini [5].

Some of the narratives in Serat Centhini presented can represent the importance of water sources around ngebel lake. Concerns about the water crisis the impact of PLTP development from the beginning should focus on mutual attention. At least the narrative of Serat Centhini is found that some of the existing water sources are sacred (important places) and boil into the lake. Although dutch records when planning the construction of irrigation Ngebel inform the abundance of water on the slopes of Mount Wilis, until the discovery of water sources at an altitude of 1000 meters. However, the contours of Mount Wilis that make up large, steep-edged basins make it difficult for water to flow to populated places [4]. The existence of Ngebel irrigation as it is today can not be denied because of the work of the colonial government that seeks to collect water from various water sources around Ngebel into the lake. Then channel it down to cover ponorogo and Madiun areas to irrigate the rice fields. This is documented in the clippings of irrigation design reports around 1916-1917.

Maintaining the harmonization of man and nature must still be interpreted by every human being. Serat Centhini, one of the ancient manuscripts, can be used to reflect how the pattern of life of the contested society (Ngebel) takes care of its nature. Moreover, the Covid19 Pandemic narrows human movement space and objects in every sector of life, forcing people to be independent and rely on nature. Humans are forced to survive at a minimum by utilizing the natural products around them. Every human being should still interpret the role of maintaining the harmonization of humans and nature. Serat Centhini, one of the ancient manuscripts, can be used to reflect how people's life patterns in context (Ngebel) care for their nature. Especially with the Covid-19 pandemic, which narrows the space for human movement and impacts every sector of life, forcing humans to be independent and rely on nature. Humans are forced to survive minimally by utilizing the natural products around them.

In these situations, humans can again reflect on the critical role of natural existence that is sometimes overlooked. Similarly, various mitistisimes cover the environment (mysticalecologists). Because basically, the emergence of mystification (myth) is closely related to the ecological wealth of the surrounding nature. The myths present need to be interpreted more deeply. Because man, as a creature of meaning seekers, man obtains meaning from dialectic processes involving three elements, namely externalization, objectivization, and internalization. All three are long processes that lead to the internalization of the concept of passion and generate new concepts, as well as the creation of myths for the preservation of nature [12]. 


\section{Conclusions}

Ngebel Ngebel area is rich with water sources so that mystical thoughts appear to maintain its sustainability as well as the attention of the Colonial government that maximizes the use of lake water, the myth of being the guardian of the sustainability of water sources in the past. Some of the records of Serat Centhini that were successfully discovered and the various changes that occurred require humans to reflect on the impact of what happens next if nature is only exploited. The development of PLTP Ngebel that is felt to have a negative impact should not only cause protests. However, there must be concrete action on the preservation of nature. There is or is no development of PLTP Ngebel man must still maintain harmony with nature.

Serat Centhini manuscript as an exotic imagination of ngebel nature of the past and the mandate of cultural development should be reflected as a step to instill a sense of responsibility to the nature ngebel. Similarly, the intertwined reciprocal relationship between man and nature, so that the nature we dwell in is not damaged, maintained its beauty. PLTP is used for shared electricity. However, natural beauty must still be taken into consideration. Do not hurt nature and fellow human beings. The more it allows nature to be damaged, the more the beauty of nature will only be exposed without any enjoyment of sight. Inseparable with manuscripts that are only adored without understanding the content and spirit of his time, only can not be perceived its beauty of the earth..

\section{References}

1. Kominfo, (2014), ESDM Jatim: Tiga WKP Geothermal Berpotensi Segera Dilelang, Retrieved from http://kominfo.jatimprov.go.id/read/umum/39330

2. E. D. Wahyunarto, (2019), Mewaspadai Ancaman Fracking PLTP Ngebel, Retrieved from http://walhijatim.or.id/2019/10/mewaspadai-ancaman-fracking-pltp-ngebel/

3. Al-Millah, PLTP: Melukai Alam Demi 120 Megawatt, 36, (2019)

4. G. J. N. Hengeveld, Geologische Onderzoekingen Ten Behoeve Van 'S Lands WaterstaatGewestelijke-En Gemeentewerken In Nederlandsch-Indie. Landsdrukkerij - weltevreden (1920).

5. F. N. F. Pratama, Korelasi Mistis-Ekologis dalam Serat Centhini Episode Pengembaraan Seh Amongraga di Telaga Ngebel Pranara, Tinjauan Antropologi Sastra, (2018)

6. O. Fathurahman, Naskah dan Rekontruksi Sejarah Lokal Islam Contoh Kasus dari Minangkabau, 7(2), (2005)

7. D. W. R. Mastuti, Kutukan dan Berkah dalam Cerita Jawa Kuna Sebuah Refleksi Sikap Arogan Para Pemilik Kekuasaan, 7(2), (2005)

8. S. Margana, Pujangga Jawa ddan Bayang-Bayang Kolonial, (2004)

9. Purwowijoyo, Babad Ponorogo Jilid 1, Ponorogo, (1984)

10. M. Nijhoff, E. J. Brill, Encyclopaedie van Nederlandsch-Indie, (1896)

11. F. N. F. Pratama, Sepenggal Alusi Sejarah Ngebel dalam Serat Centhini, (2020)

12. I. Abdullah, Kontruksi dan Reproduksi Kebudayaan, (2015) 